\title{
46XX pure gonadal dysgenesis with dysgerminoma along with leydig cells: a unique presentation
}

\author{
Apoorva Tak ${ }^{1 *}$, Pratibha Singh ${ }^{1}$, Garima Yadav', Meenakshi Rao
}

\begin{abstract}
${ }^{1}$ Department of Obstetrics and Gynecology, AIIMS, Jodhpur, Rajasthan, India
${ }^{2}$ Department of Pathology, AIIMS, Jodhpur, Rajasthan, India
\end{abstract}

Received: 21 March 2020

Accepted: 22 April 2020

\section{*Correspondence:}

Dr. Apoorva Tak,

E-mail: drapoorvatak90@gmail.com

Copyright: () the author(s), publisher and licensee Medip Academy. This is an open-access article distributed under the terms of the Creative Commons Attribution Non-Commercial License, which permits unrestricted non-commercial use, distribution, and reproduction in any medium, provided the original work is properly cited.

\section{ABSTRACT}

Authors report a unique case of 46XX gonadal dysgenesis, with dysgerminoma in one ovary and other streak ovary with hilar nests of leydig cells. It is exceptionally rare to find dysgerminoma in a dysgenetic gonad with no Y chromosome and so is the presence of leydig cells in the contralateral streak ovary in a patient with 46XX pure gonadal dysgenesis.

Keywords: 46XX gonadal dysgenesis, Leydig cells, Streak ovary, Y chromosome

\section{INTRODUCTION}

Dysgerminoma and gonadoblastoma constitute the most prevalent tumors in patients with dysgenetic gonads. ${ }^{1}$ Majority of these are associated with Y chromosome or mosaicism for $\mathrm{Y}$ chromosome. In a study, conducted on patients with dysgenetic gonads, 25 had Y chromosomal material and only 1 had pure dysgerminoma with a 46 XX karyotype. ${ }^{2}$ The absolute role of $\mathrm{Y}$ chromosome in the development of dysgerminoma in dysgenetic gonads has not been completely deciphered.

Literature reveals that even if the peripheral leukocyte chromosomes are normal, there still may be an abnormal chromosome cell line in the gonads. So conventional karyotyping alone is not sufficient. DNA hybridisation with probes to look for $\mathrm{Y}$ elements in about 10 of their common locations, should be carried out. This should include a specific assay for the centromeric and proximal long arms of the $\mathrm{Y}$ chromosome. ${ }^{3}$

\section{CASE REPORT}

A 23-year-old woman, married for 1 year, presented to us with continuous dull aching pain in lower abdomen since
10 days. She had a history of amenorrhea since past 4 months. She had her first and only spontaneous scanty menstrual flow at the age of 16 years. Since then she had experienced only withdrawal uterine bleedings after receiving estrogen-progestin medications. Pubarche and thelarche occurred around the age of 14 year. She had no past history for childhood infectious diseases. Family history was negative for genetic diseases. She had an elder sister who was married and had two children.

On physical examination, her BMI was $22.2 \mathrm{~kg} / \mathrm{m}^{2}$. The breasts were well developed with Tanner stage 4 but her axillary and pubic hair were scanty. The thyroid gland was not palpable and the external genitalia were normal.

On pelvic examination, vagina was normal and uterus was small in size. A $6 \times 6 \mathrm{~cm}$ non tender solid cystic mass was felt in the pouch of douglas separate from the uterus and bilateral fornices were free and non-tender.

On evaluation, her thyroid profile and prolactin levels were within normal limits. FSH levels were markedly elevated $(117.81 \mathrm{ng} / \mathrm{ml})$ and $\mathrm{LH}$ levels were also high $(21.63 \mathrm{ng} / \mathrm{ml})$ with low levels of $17-\beta$ estradiol (20 $\mathrm{pg} / \mathrm{ml}$ ), suggestive of hyper-gondotrophic hypogonadism. 
Karyotyping studies revealed normal 46XX pattern with no structural anomalies. Ultrasound revealed a small sized uterus with a solid left adnexal mass with increased vascularity on Doppler and few calcific foci within the lesion. Bilateral ovaries were not separately visualized. Tumor markers were done to rule out ovarian malignancy wherein her CA 125 level was $59 \mathrm{miU} / \mathrm{ml}$, LDH levels were very high $2,023 \mathrm{miU} / \mathrm{ml}$, while rest of the markers including CEA, inhibin, AFP and $\beta$ hcG were within normal limits. These features raised suspicion for dysgerminoma and her contrast enhanced CT scan reaffirmed the findings of a solid cystic left adnexal mass favoring a dysgerminoma, with few enlarged lymph nodes and mild to moderate ascites.

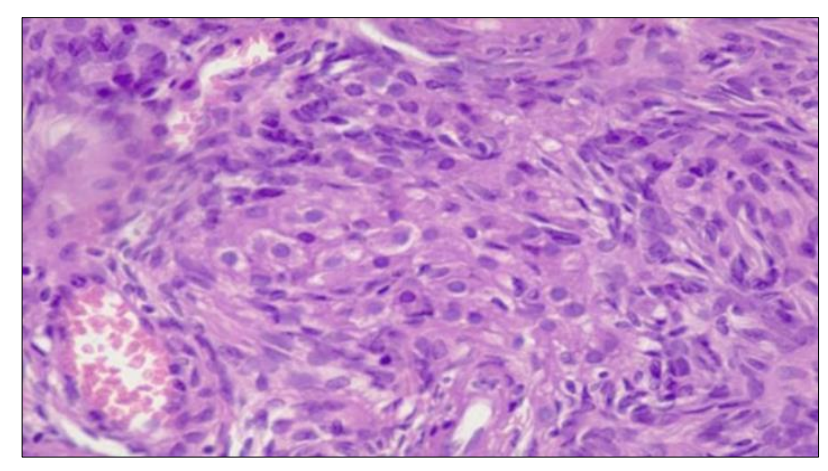

Figure 1: Leydig cells noted in centre of right streak ovary $76 \times 39 \mathrm{~mm}(300 \times 300 \mathrm{DPI})$.

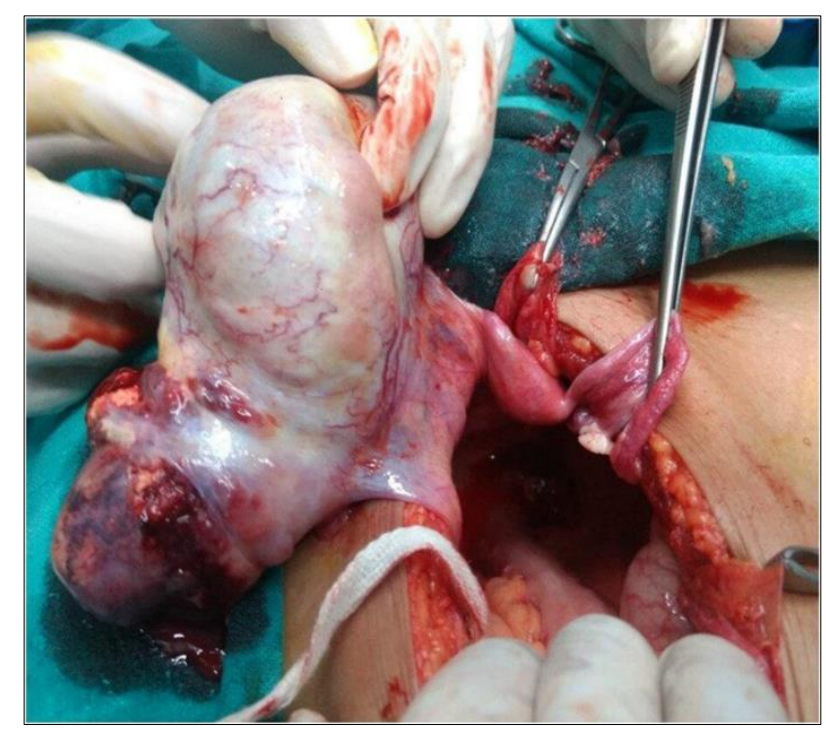

Figure 2: Intraoperative picture of dysgerminoma and streak ovary $76 \times 67 \mathrm{~mm}(300 \times 300 \mathrm{DPI})$.

As this case patient didn't show turner's phenotype and had 46XX karyotype, she was diagnosed as 46XX pure gonadal dysgenesis.

Among the differentials, is the rare Slotnick-Goldfarb syndrome (unilateral streak gonad syndrome), wherein the affected subjects are generally normal phenotypic females, under observation because of secondary amenorrhea and sterility after a period of oligomenorrhea. ${ }^{4}$ The internal genitalia are characterized by a streak gonad in the left adnexa and a hypoplastic ovary in the other. The etiology of this entity is unclear however, they suggested that the invariable distribution of gonadal laterality in these cases can be explained genetically. The total protein and DNA content of right gonads exceeds that of left, but in this case the right ovary was streak.

\section{Treatment}

Patient underwent a staging laparotomy, around $100 \mathrm{ml}$ hemorrhagic peritoneal fluid was aspirated and sent for cytology. A $6 \times 6 \mathrm{cms}$ left adnexal mass was seen with solid components and a ruptured capsule which was sent for frozen section. Left sided fallopian tube was stretched over the mass while right sided tube was normal. Right ovary was streak and the uterus were also small in size (Figure 1). Macroscopic extra-pelvic deposits were present on small bowel, large bowel and peritoneum. Multiple peritoneal biopsies were taken. Frozen section revealed dysgerminoma of the left ovary with extensive necrosis. Authors proceeded with bilateral oophorectomy with pelvic node dissection and infracolic omentectomy. Uterus was left in situ for future embryo transfer.

On final histopathology, left ovarian mass showed sheets and nests of tumor cell separated by fibrous septae infiltrated by lymphocytes suggestive of dysgerminoma. Due to extensive necrosis and calcification no, gonadal tissue was identified. Sections from right streak ovary showed ovarian parenchyma with calcification, psammoma bodies, and hilar nests of leydig cells (confirmed on IHC) along with a few leydig cells in the ovarian stroma which were noticed away from the hilum (Figure 2). Presence of leydig cells was suggestive of a testicular mass, but surprisingly the karyotype from peripheral leucocytes done earlier had not revealed any $\mathrm{Y}$ element.

\section{Outcome and follow-up}

Being stage IIIB dysgerminoma, this case patient is planned for 4 cycles of BEP chemotherapy. Patient is currently receiving her 1st cycle of chemotherapy and is in case follow up. Her LDH levels in the post-operative levels fell significantly and now she is planned for follow up every month with LDH levels for the first year.

\section{DISCUSSION}

In contrast to the slow growing epithelial ovarian tumors, germ cell malignancies grow rapidly and commonly present with pelvic pain related to capsular distention, hemorrhage or necrosis.

About 5\% of dysgerminomas are discovered in phenotypic women with abnormal gonads. For most patients with gonadal dysgenesis, dysgerminomas arise in 
gonadoblastoma, which are benign tumors composed of germ cells and sex cord stroma. About 50\% gonadoblastomas developed into dysgerminoma. ${ }^{5}$

Dysgerminomas are highly chemo-sensitive and the fiveyear survival with negative nodes is $95.7 \%$. Although recurrences are uncommon, $75 \%$ will occur within the first year after treatment. Strict follow-up is recommended up with monthly LDH levels for first year, then tumor markers every 2 months for $2^{\text {nd }}$ year, and 3 monthlies for $3^{\text {rd }}$ year and 6 monthly for 5 years along with abdominopelvic imaging. ${ }^{6}$

Gonadoblastomas are found in $25 \%-30 \%$ of patients with XY gonadal dysgenesis and in $15 \%-20 \%$ of $45 \mathrm{X} / 46 \mathrm{XY}$ individuals. $^{7}$ Only a small proportion of gonadoblastoma develop in 46XX females with no evidence of $\mathrm{Y}$ chromosome. The gonadoblastoma locus is the only oncogenic locus on the human Y chromosome. ${ }^{8}$ About 10 cases of gonadoblastoma have been reported in normal XX karyotype by Esin et al, but in this case due to extensive degeneration and necrosis exact gonadal tissue could not be obtained. ${ }^{9}$ Gonadal dysgenesis encompasses a great number of chromosomal and phenotypical variants. ${ }^{10}$ The patients with gonadal dysgenesis can be grouped according to the following karyotypes $45 \mathrm{X}$ (50\%), mosaics (25\%), 46XX (25\%). ${ }^{11}$

Commonly gonadal dysgenesis doesn't lead to breast development as a result of low levels of circulating estradiol. However, this case results were consistent with the Marrakchi et al, wherein development of secondary sexual characters was noted. ${ }^{12}$ Furthermore, NamavarJahromi et al presented three sisters with 46, XX PGD, who were born from a first cousin marriage. They were examples of tumors in PGD without an identifiable $\mathrm{Y}$ chromosome. ${ }^{13}$

According to the results, it seems prudent that clinicians should consider different presentations for pure gonadal dysgenesis Usually tumorigenesis occurs in patients with identifiable $\mathrm{Y}$ chromosome, however malignant degeneration of the streak gonads in the patients with 46, XX pure gonadal dysgenesis can also be noted. Therefore, prompt diagnosis and follow-up should be recommended. ${ }^{14}$

Funding: No funding sources

Conflict of interest: None declared

Ethical approval: Not required

\section{REFERENCES}

1. McDonough PG, Byrd JR, Tho PT, Mahesh VB. Phenotypic and cytogenetic findings in eighty-two patients with ovarian failure-changing trends. Fertil Steril. 1977;28(6):638-41.

2. Troche VL, Hernandez EN. Neoplasia arising in dysgenetic gonads. Obstet Gynecol Surv. 1986;41(2):74-9.

3. Rasmussen O, Ives J, Carlan SJ. Ultrasound of a patient with gonadal dysgenesis and mixed malignant germ cell tumor. J Diag Med Sonograph. 2002;18(3):150-3.

4. Ghirardini G, La Sala G. The unilateral streak gonad syndrome (Slotnick-Goldfarb syndrome). Eu J Obstet Gynecol Reprod Biol. 1981;12(5):287-95.

5. Kanagal DV, Kishan Prasad AR, Kumar RG, Cherian S, Shetty H, Shetty PK. Ovarian gonadoblastoma with dysgerminoma in a young girl with 46XX karyotype: a case report. J Clin Diag Res. 2013;7(9):2021.

6. Berek JS. Berek and Novak's gynecology. Lippincott Williams and Wilkins; 2019.

7. Kulkarni MM, Khandeparkar SG, Joshi AR, Bhayekar PV. Unilateral gonadoblastoma with dysgerminoma in normal fertile woman having a child: extremely rare occurrence with characteristic immunohistomorphology. Indian J Pathol Microbiol. 2016;59(4):527.

8. Esin S, Baser E, Kucukozkan T, Magden HA. Ovarian gonadoblastoma with dysgerminoma in a 15 -year-old girl with 46XX karyotype: case report and review of the literature. Arch Gynecol Obstet. 2012;285(2):447-51.

9. Taylor HS, Pal L, Sell E. Speroff's clinical gynecologic endocrinology and infertility. Lippincott Williams and Wilkins; 2019.

10. Sushma Bharti MD, Sisodia SM, Ali Z. Bilateral gonadoblastoma with extensive calcification in $46 \mathrm{XX}$ karyotype female-a rare case report. J Med Sci Clin Res. 2018;6(9):942-4.

11. Marrakchi A, Belhaj L, Boussouf H, Chraibi A, Kadiri A. Pure gonadal dysgenesis XX and XY: observations in fifteen patients. In Ann D'endocrinol. 2005;66(6):553-6.

12. Namavar-Jahromi B, Mohit M, Kumar PV. Familial dysgerminoma associated with $46, \mathrm{XX}$ pure gonadal dysgenesis. Saudi Med J. 2005;26(5):872-4.

13. Kohmanaee S, Dalili S, Rad AH. Pure gonadal dysgenesis (46 XX type) with a familial pattern. Adv Biomed Res. 2015;4:162.

14. Maeyama M, Kagami T, Miyakawa I, Tooya T, Kawasaki N, Iwamasa T. Case report of dysgerminoma in a patient with $46, \mathrm{XX}$ pure gonadal dysgenesis. Gynecol Oncol. 1983;16(3):405-13.

Cite this article as: Tak A, Singh $\mathrm{P}$, Yadav G, Rao M. 46XX pure gonadal dysgenesis with dysgerminoma along with leydig cells: a unique presentation. Int J Reprod Contracept Obstet Gynecol 2020;9:2619-21. 